\title{
Good Parks - Bad Parks: The Influence of Perceptions of Location on WTP and Preference Motives for Urban Parks
}

This is the peer reviewed version of the following article:

Original:

Andrews, B., Ferrini, S., Bateman, I. (2017). Good Parks - Bad Parks: The Influence of Perceptions of Location on WTP and Preference Motives for Urban Parks. JOURNAL OF ENVIRONMENTAL PLANNING AND MANAGEMENT, 6(2), 204-224 [10.1080/21606544.2016.1268543].

Availability:

This version is availablehttp://hdl.handle.net/11365/1005071

since 2017-03-27T13:51:29Z

\section{Published:}

DOI:10.1080/21606544.2016.1268543

Terms of use:

Open Access

The terms and conditions for the reuse of this version of the manuscript are specified in the publishing policy. Works made available under a Creative Commons license can be used according to the terms and conditions of said license.

For all terms of use and more information see the publisher's website.

(Article begins on next page) 


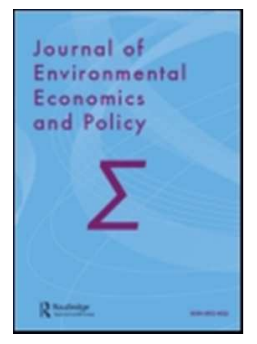

Good Parks - Bad Parks: The Influence of Perceptions of Location on WTP and Preference Motives for Urban Parks

\begin{tabular}{|r|l|}
\hline Journal: & Journal of Environmental Economics and Policy \\
\hline Manuscript ID & TEEP-2016-0020.R2 \\
\hline Manuscript Type: & Original Article \\
\hline Keywords: & Parks, WTP, Distance Decay, GAM \\
\hline \multicolumn{2}{l}{} \\
\hline
\end{tabular}

SCHOLARONE ${ }^{m}$

Manuscripts 


\title{
Good Parks - Bad Parks: The Influence of
}

\section{Perceptions of Location on WTP and}

\section{Preference Motives for Urban Parks}

\author{
Abstract \\ Urban parks generate substantial public benefits yet explicit economic assessments of such \\ values remain relatively rare. Surveys of willingness to pay (WTP) were undertaken to assess \\ such values for proposed new parks. The analysis assessed how preference motives and \\ values varied according to the location of parks. Results revealed greater altruistic \\ motivation and higher overall values for the creation of inner city as opposed to suburban \\ parks. Spatial decomposition revealed that, after controlling for other determinants such as \\ incomes, values generally increase for households closer to proposed parks, but that a \\ significant downturn in values is evident for households located very close to a proposed \\ inner city park; a finding which echoes concerns regarding the potential for such sites to \\ provide a focus for antisocial behaviour. While these findings provide strong overall support \\ for provision of public parks they highlight the importance of perceptions of location and \\ the potential for localised dis-benefits. \\ Key Words \\ Parks, WTP, Distance Decay, GAM.
}




\section{Introduction}

Urban parks and other green spaces provide a wealth of benefits to urban residents. These include cultural services such as the provision of unique recreation and leisure opportunities as well as an array of ecosystem services including noise and pollution abatement (Whitford et al, 2001), climate and hazard regulation (see Davies et al., 2010 for a thorough review). Outdoor activity programs have even been shown to offer similar cost-effectiveness to behavioural therapy for social recovery in those living with mental illness (Willis et al., 2016). This wide range of benefits combined with an ever increasing demand for natural landscapes within increasingly populous urban areas of the UK results in public parks and green spaces being some of the most valuable land in the British landscape (Bateman et al. 2011).

Given this, the number of primary valuation studies of UK urban parks is surprising low (CabeSpace, 2005; Dehring \& Dunse, 2006; Hanley \& Knight, 1992). The present study sets out in part to address this research gap, using one of the longest serving approaches to estimating non-market values; the contingent valuation (CV) method (Mitchell and Carson 1989; Loomis, 2012; Mahieu et al., 2014). Here the approach is used to directly ask survey respondents what they would be willing to pay (WTP) for the creation of new public parks in the city of Norwich, UK. In addition, this study investigates the importance of the environmental attributes individuals perceive at different proposed park locations and the attitudes of the residents themselves. One of the major objectives of this paper is to explore commonly held assumptions regarding the distance decay of WTP values for environmental assets. This is achieved through the use of novel statistical techniques within a parsimonious 
model of the determinants of WTP that includes both traditionally considered economic and spatial, as well as less commonly considered, attitudinal determinants of WTP.

\section{Distance Decay in WTP}

Previous stated and revealed preference studies have found that WTP for environmental assets such as urban parks decreases with increasing distance from the good (Salazar \& Menendez, 2005; Garcia, 2014). Here it is presumed that as distance to the good increases, the costs of access rise and so does the ratio of users to non-users. As users are considered to hold higher values than non-users the overall result is that average WTP declines with increasing distance (Bateman et al. 2006).

While distance decay for public goods is often presumed to be linear and non-decreasing numerous hedonic pricing studies have found quadratic or inverted $U$ shape relationships with proximity to a range of goods such as schools, transport hubs and shops (Day et al 2007). Here it is presumed that people want to be close to reduce travel costs, but far enough away to avoid potential local disamenities such as, noise and traffic. Indeed the value of proximity has been shown to vary for different property types (Dehring \& Dunse, 2006) neighbourhood characteristics (Anderson \& West, 2006) and park types (Espey \& Owusu-Edusei, 2001). For example, Dunse et al., (2007) found that houses located on park edges exhibit insignificant or significantly negative relationships with distance, while flats located on park edges exhibit significant positive relationships with distance. The authors speculate that issues of security and perceptions of anti-social behaviour drive these local disamenities for houses but for residents of flats the benefits of proximity outweigh any 
local disamenities. Perceptions of nuisances (such as vandalism ${ }^{1}$ and youngsters hanging around) have been ranked as more important than the presence of facilities (such as cafes, and the presence of trees) by older people in Britain (Aspinall et al., 2010).

The existence of non-monotonic distance decay relationships has implications for both park management and planning, as well as the use of value transfer techniques (Johnston et al., 2015; Simpson, 2016) for valuing urban parks and other pubic goods. Value transfer techniques make use of existing valuations to generate values for sites where no assessments exist. While value transfers may only ever be a substitute, the reduction in costs compared to primary valuations have resulted in value transfers becoming common practice for recreational and natural sites (Rosenberger \& Loomis, 2001; NRC, 2005). Assumptions of monotonic distance decay relationships feature heavily in value functions used for the transfer of values to sites for which no primary valuations exist (e.g. Bateman and Langford 1997; Pate and Loomis 1997; Bateman et al., 2006; Day et al., 2007; Bateman et al., 2011). The prevalence of assumptions regarding linear distance decay in the value transfer literature is epitomised by recommendations that the presence of monotonic distance decay be used as validation of the theoretical expectations of economic theory when considering the validity of both primary valuations and values derived from transfers (Bateman et al., 2010). In this study the potential for complex distance decay relationships are explored through the use of flexible semi-parametric approaches (Ferrini and Fezzi, 2012) to the modelling of WTP bids which through the use of smoothing functions avoid the imposition of specific functional forms onto the modelling of consumer preferences.

\footnotetext{
${ }^{1}$ A UK based poll showed that whilst $91 \%$ of people agreed that public parks and open spaces improve their quality of life, one in five respondents felt that investing money in park maintenance was not justified due to vandalism of park facilities (CABE, 2005).
} 
In addition to the use values that urban parks provide they may also provide significant nonuse values (including the utility others gain from there usage or potential usage). Previous studies have demonstrated that attitudes can be a significant predictor of WTP for non-use values such as the protection of endangered species (Kotchen \& Reiling, 2000). Hanley et al. (2003) found that use values decreased more rapidly with distance than non-use values and suggests that distance decay will vary both spatially within a resource type and across different resource types. As stated preference methods measure both use and non-use values, a proxy measure of environmental concern was included to account for the potential influence of other regarding attitudes on WTP. While attitudes are object specific, values are general and abstract and often exhibit weak relationships with behaviour. As such the General Awareness of Consequences (GAC) scale was employed to measure a general attitude towards environmental behaviour. It is a condensed version of the awareness of consequences scale (Stern et al., 1993) and has been shown to be very similar to the NEP scale (Stern et al., 1995) but with a greater focus on detecting underlying values such as altruism and self-transcendence. Studies have shown that individuals with self-transcendent and collective values are more willing to engage in different forms of altruistic, cooperative, or pro-environmental behaviour than those with individualistic or self-enhancement values (Nordlund and Garvill: Karp, 1996; Schwartz, 1992; Stern \& Dietz 1994; Stern, Dietz \& Black 1985-1986; Stern, et al.,, 1995). By accounting for the heterogeneous nature of participants other regarding attitudes the influence that such attitudes have on WTP can be observed in addition to any differences in the influence of attitudes on WTP between the two locations. 
In this study two locations which were both plausible whilst differing in their potential to be perceived as generating local disamenities and other regarding values were chosen for valuation. By proposing two parks with identical facilities that vary only in their location, differences in both WTP values and motivations can be attributed to differences in perceptions of the proposed locations. The first park, located in the city centre (CC) represents a highly accessible location however the area is visibly run down being home to an unfinished shopping complex (Anglia Square). While the CC location promises greater social benefits in terms of its accessible and deprived location this is a double edged sword as this run-down area is known to be frequented by substance abusers. It is possible that if distance decay in values is detectable then it will be non-monotonic due to the presence of local disamenities at the CC location. The second park (SB) was located near the outer ring road in a suburban location. The locations of the proposed parks can be seen in Figure 1 below. Although neither site is intended to be the best site for a new park, the two sites are for the most comparable, being next to large roads and shopping facilities; in addition, both imply redevelopment of disused buildings.

While the creation of both parks would involve urban re-development, the creation of the city centre park would involve highly visible changes in a clearly run-down area including the removal of a well-known abandoned building. It is hypothesised that both of these factors will contribute to the relative "other regarding" value perceived to be created by the two locations by residents and thus make the $\mathrm{CC}$ location more appealing to those with altruistic attitudes.

Figure 1 ABOUT HERE 


\section{Study Aims}

In this study the potential for CV methods to measure the benefits of urban parks in Norwich, UK is explored. Due to the innate spatial nature of these goods particular attention is paid to the role that spatial relationships have in the modelling of WTP for urban parks. These spatial relationships have broader implications for environmental valuation as they are used extensively in both stated and revealed preference valuations. Spatial variables such as distance are used both in the construction of value functions and in determining aggregation areas without having to rely on political jurisdictions in addition to increasingly being found in value transfer techniques.

i) To provide economic value estimates for the creation of two new parks in Norwich.

ii) To explore the influence of environmental attitudes on WTP for two new parks in Norwich.

iii) To explore spatial relationships that influence WTP for new parks in Norwich.

\section{Methods}

In accordance with the recommendations of the NOAA panel (Arrow et al., 1993) surveys were administered face to face at participant's homes. This enabled us to remind respondents of their budgetary constraints as well as the existence of potential substitute sites. Participants were informed that "we are researching the value of parks to the people of Norwich" and wished to interview people about their experiences and views. Interviewers were recruited internally from the university student population and were selected to facilitate testing of interviewer biases. All interviewers had a smart professional appearance and carried university ID cards so that participants could confirm their identity. 
Strict ethical guidelines were followed by the interviewers who made it clear to participants that their participation was entirely voluntary, that their data could be removed from the study at any point upon their request and importantly that the parks they were valuing were entirely theoretical and the results would only be used for research purposes.

The study area was defined by drawing a 1.5 mile circular buffer around each proposed park location. These two circles were joined together and a grid of $96,500 \mathrm{~m}^{2}$ sampling squares (shown in Figure 4.1) draped over this area. The resulting study area has the advantage of covering the majority of the Norwich city local authority area whilst also extending to the edge of the greater Norwich area (see Figure 1). In an attempt to obtain a representative range of sample squares for interviewers to canvas, the straight line distance to each park was calculated for every postcode centroid and averaged for each sample square. In addition the average IMD (2007) English index of multiple deprivation scores for all postcode centroids within each study square were obtained and averaged. Averaged distance and deprivation scores for each study square were plotted against each other. Squares were then sampled from the resulting plot to provide a representative set both in terms of deprivation and distance to each of the parks. 


\subsection{Park Choice and WTP Questions}

Previous researchers (Dijkstra et al., 2003) have asserted that the use of pictorial representations in evaluation tasks improve task realism, as such participants were shown stock photos of a verdant English park and informed that the park once complete would look like the photograph (see Appendix 1). The same photo was used to represent both proposed parks further re-enforcing to participants that the two parks were equivalent apart from their location whilst avoiding known problems with the disproportionate influence of irrelevant pictorial attributes (Laing et al., 2008). In order to establish the direction of participant's preferences and ensure participants had understood our proposal participants were asked which of the two parks they would prefer to be created if only one could be created. Participants were asked in an open ended format to explain their choice and to categorise their expected usage of the park into one of four categories. Assuming participants were familiar with the goods in question and that sufficient information had been provided for them to understand our proposal, interviewers explained that the significant costs of creating the new parks would be met through an increase in their annual council tax bill. In the UK both owners and tenants are liable for the payment of annual council tax bills which are charged on a per property basis. The amount payable is determined by the national valuation band for the home (based on 1991 assumed capital values), how much the local council charges for that band and whether the occupier is eligible to any discounts or exemptions. Those exempt from payment include under $18 \mathrm{~s}$, individuals with severe mental impairments live in carers and full time students. Average annual council tax bills in England at the time of this study ranged from $£ 964$ to $£ 2878$ (for property values $=<£ 40,000$ and $>£ 320,000$ respectively) DCLG (2013). 
Council tax was chosen over an entry fee due to its compatibility with the public provisioning of urban parks in the UK, it is also a payment vehicle with which the majority of adults have experience, Vondolia et al., (2014) suggests that experience with a payment vehicle reduces protest bids. Council tax has been used as a payment vehicle in recent contingent valuations of public libraries, which are also funded through council tax (Fujiwara et al., 2015). A compulsory payment vehicle such as a tax increase also has the added advantage of reducing free riding behaviour. It thus makes fairness implicit in the valuation increasing the weight of other regarding motives. In order to compare the effect of the park locations, each participant was asked three valuation questions, their maximum WTP for the creation of: i) the CC park alone; (ii) the SB park alone; (iii) the creation of both Parks ${ }^{2}$. A payment ladder flashcard was presented to participants to select values from (see Appendix 2). In order to rule out potential ordering effects (Halvorsen, 1996) the order in which the park valuation questions were presented was reversed on alternate sampling days.

\subsection{Protest Bids}

The presence of protest bids can introduce significant bias into WTP results, a problem confounded by the lack of any consensus on how they should be treated (Boyle and Bergstrom, 1999, Meyerhoff and Liebe, 2006). Their inclusion can lead to a downward bias in predicted values (driven by non-economic motives) while there removal can lead to a selfselection bias in the sample. This is particular important given our interest in non-economic motives. Protest bids are defined as a response which does not reflect the respondents genuine WTP but instead a zero or an unrealistically high or low value (Bateman et al., 2002). While true zeroes are the reservation price for individuals who are indifferent to the

\footnotetext{
${ }^{2}$ Collecting values for the creation of both parks allows us to observe any diminishment in values when compared against the value of a single park.
} 
proposed change (Strazzera et al., 2003). To distinguish between the two, an open ended question asking participants to explain the reasons for a zero bid was used. An optional don't know response was offered to accommodate participants who did not have sufficient information to complete the valuation.

\subsection{Participant Characteristics}

Key socio-demographic variables were collected from each participant including age, gender, the number of adults and under $18 \mathrm{~s}$ in the household, total household income and the number of cars available to the household. Budgetary constraint was measured using both the number of dependents (under 18) and the total annual household income. Altruistic attitudes were proxied by measuring participant's environmental concern with the general awareness of consequences scale. The GAC was administered in its original selfcomplete format towards the end of the survey. To minimize potential bias in the GAC participants were re-assured that interviewers would not see their responses and were given an envelope in which to seal their completed scale.

The distance from each participant's geographic postcode centroid to the geographic centroid of the two parks was calculated using ArcGIS network analysis and the Ordnance Survey Integrated Transport Network (TM). Norwich postcodes can contain anything from 1 to 100 addresses and as such the use of postcode centroids introduces a significant amount of spatial error in distance calculations and significantly reduces the variability in the distance variable as many participants shared the same postcode. The average size of the postcode polygons used in this study was $14639 \mathrm{~m}^{2}$ (with a range of $456 \mathrm{~m}^{2}$ to $102255 \mathrm{~m}^{2}$, std dev $\left.=15708 \mathrm{~m}^{2}\right)$. (November 2007 version of the NSPD used). 


\section{Results}

Three interviewers collected 386 completed surveys ${ }^{3} .64$ participants refused to value the CC park and 61 the SB park Follow up questions revealed that the majority of these responses were attributable to the payment vehicle. These participants felt that council tax was already too high and refused to pay any more on this basis. A further 13 participants gave don't know responses for the value of park A (14 for park B) and 4 participants gave bids over $\mathrm{f} 150$ for the CC park ( 5 for the SB park). Out of the original sample of 386 participants, 37 failed to provide their household income. Removal of these participants and the above outliers gives a final sample of 270 participants with 270 bids for the CC park and 268 for the SB park.

No significant differences were found between the means of the study variables between the two ordering treatments ruling out any potential ordering effects. Comparison of socio demographic characteristics of our sample with the study area reveals no significant differences in the distributions of age in our sample and those calculated from the 2001 census $^{4}$ for every postcode in the study area $(z=-0.399,0.69)$. Comparison of income values ${ }^{5}$ reveals that the distribution of incomes is significantly higher in the study area. While there was a significantly higher number of dependents per household than the average for the

\footnotetext{
${ }^{3}$ Two male (22 and 26 years) and one female (51 years) interviewers were recruited, no significant differences were found between the estimated age of refusals and respondents $(t=-0.111, p=$ 0.912). 568 individuals declined to be interviewed giving a 40\% response rate. Of those who declined $53 \%$ were female and $46 \%$ male. This study was conducted in September 2009.

${ }^{4}$ Mean ages were calculated from mid points of census frequency data for all over $18 \mathrm{~s}$.

${ }^{5}$ Study area median household incomes were extracted from the Experian Mosaic data set at the LSOA level.
} 
study area. These test results and descriptive statistics for both our sample and the study area can be found in Appendix 3.

\subsection{Environmental Attitudes}

The GAC scale measures individual's environmental concern by asking participants how much they agree with statements regarding environmental degradation and protection. While the GAC scale is designed to measure 3 value orientations (biospheric, egoistic and altruistic) based on if the action occurs to avoid consequences for nature, the self or others respectively. Factor analysis of the GAC item scores revealed a lack of clear dimensionality in terms of the three value orientations, confirming the results of (Ryan \& Spash, 2008) who found that the GAC scale cannot be relied on to describe three value orientations. As a result all subsequent analysis utilises the mean of all GAC item scores.

\subsection{Park Choice Results}

246 Participants stated that they would prefer the CC park to be created over the SB park leaving 133 choosing CC and seven giving a don't know response (Table 1). Showing a clear preference for the creation of the CC park. Qualitative responses explaining why participants chose each park were grouped according to their motivation resulting in 14 motivation categories ${ }^{6}$. Roughly $47 \%$ of those who chose CC referenced the city centre location, a need for regeneration, a need for green space in the area and altruistic reasons (would benefit others around the location) in their qualitative responses to why they chose each park. Indicating that a significant number of people expressed a preference for the CC

\footnotetext{
${ }^{6}$ Categorised reasons given for choosing the CC park: prefer the CC Location, presence of alternatives around SB location, prefer city centre location, location in need of regeneration. Reasons for choosing the SB park: dislike the CC location, SB location more rural, prefer SB location, lesser of two evils, CC location not big enough, easier parking at the SB location. Reasons which were present for either park choice: would use more, would benefit others around the location, need for greenspace around location and better access.
} 
park based on its location. In contrast, the reasons given for choosing the SB location where dominated by distance, access and a dislike of the Anglia square area (CC park location). $70 \%$ of the sample chose the park closest to them, however of the 118 not choosing their closest park, some 81 (nearly 70\%) chose the CC park. Indeed only 55\% of those living closer to Park SB actually chose the latter as their preference. Taken together these results show a strong overall preference for the CC location ${ }^{7}$.

Table 1:

(Table here)

A Probit model was fitted to participant's Boolean park choice response coded so that one represents a choice of the SB location and zero the CC. Results of this model are shown in Table 2. The natural log of distance to the CC location has a significant and positive effect on park choice showing that the further away from the cc location participants are, the more likely they were to choose SB ceteris paribus. The coefficient for the natural log of distance to the SB location is negative indicating that the further away from Park B the less likely you are to choose the SB location ceteris paribus. The mean total GAC score also shows a significant negative relationship with the likelihood of choosing SB indicating that participants who express greater environmental concern are less likely to choose the SB location. This provides clear evidence that participant's preferences over the two locations are significantly influenced by their environmental concern. The categorical park use

\footnotetext{
${ }^{7}$ Comparison of the incomes of those who choose park $B$ with those who choose park A shows no significance difference (Mann-Whitney $N=280 z=0.554 p=0.5798$ ). Comparison of the gender split of the two park choice categories also shows no significant difference with $43.84 \%$ of those choosing A being male compared to $45.54 \%$ of those who choose B.
} 
variable was converted into a single dummy variable with one equal to a participant intending to use a park at the SB location. Increasing intended usage has a significant positive effect on participant's choice of SB. The inclusion of use variables and distance is potentially problematic due to expected confounding; however the strongest correlation was found between the distance to SB and use of SB variable was relatively low $(-0.3824)$.

Table 2:

(Table here)

\subsection{WTP Results}

Comparing the WTP bids for the two locations using a t-test confirms a significant difference $(t=3.411, p<0.001)$ with the CC park location having higher mean WTP. Participants were classified as users and non-users based on their response to the park usage questions. Users have higher mean WTP than non-users while also living closer to the park being valued (Table 3). Kurtosis tests confirm that the distance, income and GAC measures are nonnormal and thus non-parametric (Wilcoxon rank sum) tests of difference were performed between user and non-user groups. Significant differences were found between the distance of users and non-users of both the CC park $(Z=-4.890, p=0.000)$ and the SB park $(Z=-5.930, p=0.000)$. While no significant differences were found in the distribution of income values for both the CC park $(z=2.145 p=0.0320)$ and the SB park $(z=1.947 p=$ 0.0515). Mean GAC scores for the CC park are higher for non-users than users while for the SB park they are higher for users than non-users. Mann Whitney tests on the difference between the GAC scores of users and non-users show a significant difference for the CC park $(z=2.815 p=0.0049 N=319)$ and the SB park $(z=-2.306, p=0.0211, N=317)$. 


\section{Table 3:}

\section{(Table here)}

\subsection{Marginal Effects}

To test whether WTP values are diminished when valuing multiple parks the sum of WTP values for the CC and SB park were compared with the WTP values given for the creation of both parks. A t-test confirms a significant difference between the means of WTP for both parks and the sum of WTP for both parks $(t=8.0202 p=0.0000)$. This implies that there is a diminishment of WTP values when valuing the creation of more than one park.

\subsection{Testing for Preference Reversals}

Our study design permits us to examine the preference reversal phenomenon first reported by Slovic \& Lichtenstein (1983). This occurs where a respondent faces the choice between two options and can expresses values for both. Slovic \& Lichtenstein note that in their experiment in a significant minority of cases the chosen option did not receive the highest valuation. It can be seen from Table 4 that of those who choose the CC park some 97 participants were willing to pay more for $\mathrm{CC}$ while 3 were willing to pay more for SB, and of those who chose SB just 4 were willing to pay more for CC while 42 people were willing to pay more for SB. This preference anomaly is quite clearly not present in our own experiment. This finding affords an interesting perspective on the original Slovic \& Lichtenstein study, which concerned choices between and valuations of casino gambles. Bateman et al., (2008) provides evidence to suggest that the occurrence of such preference anomalies may be positively linked to the degree of uncertainty experienced by respondents. The lack of preference reversal in our study suggests that a high familiarity 
with the goods in question engendered low levels of uncertainty. This finding tends to reinforce the credibility of our overall valuation and choice results.

\section{Table 4:}

\section{(Table here)}

\subsection{WTP Models}

Initially Tobit models were fitted for each park, testing linear, log and quadratic forms of distance. Here the strongest (quadratic distance) models are reported in Table 5 (see Appendix 4 for all Tobit models). A positive effect of median household income on WTP was found but this was only significant for the SB park. The number of dependents (under 18s) in the household had a significant negative effect on WTP for both parks. These results are consistent with the effects of a budgetary constraint on WTP which appears to be more pronounced for the SB park.

The mean of all GAC scale items showed a significant and positive effect on WTP ceteris paribus for the CC park but no significant effect on WTP for the SB park. This confirms that non-economic motives can have a significant effect on WTP but that the significance of attitudes to WTP bids is dependent on the location of the park. The absence of a significant effect of GAC on WTP for the SB park suggests that participants WTP is based on use based motives. This is further emphasised by the significance of distance for all functional forms of distance for the SB park (see Appendix 4). WTP for the CC park appears more sensitive to the functional form of distance with only the quadratic form achieving statistical significance. To test for a moderating effect of attitudes on distance decay an interaction term between GAC and distance was included in each Tobit model. No evidence was found 
for an interaction effect for either park. By testing the Tobit specification against the alternative model that is non-linear in its regressors and contains a heteroskedastic and non-normally distributed error term ${ }^{8}$ both Tobit models were found to be miss-specified (CC park $I m=43.69$, critical Im at a $10 \%$ significance $=2.83$, SB park $\operatorname{Im}=36.74$, critical Im @ $10 \%$ $=3.58)$. As a result the coefficients produced from these models whilst informative are unreliable.

Based on Ferrini \& Fezzi (2012) Generalised Additive Models (GAMs) were used in an attempt to incorporate non-linear relationships through the use of smoothing functions and achieve a correctly specified model (Table 5). Given the theoretical importance of distance in WTP for spatial goods (e.g. Bateman et al., 2006) and the apparent sensitivity of our prior models to the functional form of distance, the GAM model were used to apply a nonparametric smoothing function to the distance measures within a Poisson log link regression model. This avoids the need to impose a priori assumptions concerning the shape of the distance decay. It also has the advantage of allowing us to further explore potential interaction effects between distance and attitudes without the confounding that would result from including both a quadratic and $\mathrm{GAC}^{*}$ distance interaction. The number of dependents and median household income remain as standard parametric variables as in the prior Tobit models.

\footnotetext{
8 Using Stata's bctobit command
} 
Table 5:

\section{(Table here)}

The GAM models show a similar pattern of results to the Tobit models, again the GAC score only has a significant positive effect on WTP for the CC location, confirming our initial suspicions that this location is perceived to offer more altruistic value. The effects of income and the number of dependents in the GAM models are reassuringly consistent with the Tobit models. The EDF (effective degrees of freedom) of the distance smoothing functions (Table 4.5) indicates the estimated degree of "wiggliness", an EDF of one would indicate that the best approximation of the smoothing function would be linear. Again no evidence for an interaction between GAC and the smoothed distance function was found.

\subsection{Evidence for the localised dis-amenity of city centre parks}

Figure 2 shows canonical plots of our smoothed distance parameters both distance variables are clearly nonlinear (with the SB model closer to linearity than the CC park) and both coefficients are significant. By not implying rigid assumptions concerning the functional form of distance decay relationships distinct differences in the shape and statistical significance of distance WTP relationships can be observed. For the CC park, WTP increases with distance until approximately 3000 metres at which point it starts to decrease with distance. This is contrasted by the slope of the smoothing function for distance to park B which shows decreasing WTP with distance up to approximately 4000 metres at which point it plateaus and then turns slightly positive likely due to the reduced number of observations at these high distances. This $\mathrm{n}$ shaped curve confirms our suspicions that despite the overall preference shown by participants for the CC park it exhibits local disamenities. 
Figure 2:

(Figure here)

There is a consistent difference in the distribution of predicted WTP values for the two parks

(Figure 3) with median WTP for the CC park being consistently higher and exhibiting a

broader distribution.

Figure 3:

(Figure here)

To demonstrate the difference between the GAM and Tobit models reported above, Figure 4 and 5 below show mean household WTP for the CC park predicted for all postcodes in the study area (details of data sources used for out of sample predictions can be viewed in Appendix 5). The Tobit map on the left shows the expected monotonic decay with values decreasing with increasing road distances from the CC park. While the GAM map shows a large local disamenities with lower mean WTP in the immediate vicinity of the CC park which steadily increases before decreasing.

Figure 4:

(Figure here)

Figure 5:

(Figure here) 


\subsection{Aggregation}

In a decision making context the total annual benefit that a new park could bring is more useful to policymakers than mean WTP values. Whilst it is possible to simply estimate the total annual benefits by multiplying the average WTP for each park by the number of households in the aggregation area required, this would not allow for the fact that the population of households may exhibit different distances and incomes than our sample. If it is presumed that the sample is representative of the wider population then the relationships with WTP should hold for the population (i.e. coefficients for the sample will be the same as for the population). Similarly relationships between WTP and distance should hold, allowing a value function transfer to be made. Here the WTP model is used to predict the WTP for areas without WTP responses.

Aggregated values of the two parks for the study area and a larger 10 mile buffer of the city center are presented in Table 6 below. The first row shows a simple aggregation based on the mean WTP of each park. For the Tobit and GAM based aggregations two sets of aggregations are presented. The first treats the preferences of protestors as if they are the same as non-protestors (i.e. by excluding them). This method may well over estimate aggregate WTP as a result of ignoring the preferences of protestors. The second method presumes that protest zeros are genuine economic preferences and thus uses the protest rate of the sample to set $6.5 \%$ of households in each aggregation population to a WTP of zero. If these aggregations are compared for the study area it can be seen that the Tobit models produce very similar aggregate values for park $A$ (Mean based $=£ 1,130,674$, Tobit based $=£ 1,297,970)$ when protestors are ignored. The inclusion of a lower bound to account for protestors in the Tobit model also resulted in similar values to the equivalent mean 
based aggregation ( mean based $=£ 933,302$ Tobit based $=1,140,256)$. The study area aggregations based on the GAM model were relatively similar but lower than those based on the Tobit models and thus even closer to the mean based aggregations.

\section{Table 6:}

\section{(Table here)}

The expansion of the aggregations to a ten-mile circular buffer of Norwich results in a significant difference between the Tobit and GAM based aggregations. The GAM models produce significantly lower aggregate values than the Tobit and the gap between the two parks begins to decrease. This is to be expected as the GAM models are trained on a set of distances with a much lower range than those used in the ten-mile aggregation. While these models are theoretically more accurate in their ability to estimate the functional form of non-linear variables they represent a trade-off in terms of a loss of predictive power for out of sample data.

\section{Discussion and Conclusion}

Results of the CV survey presented in this paper confirm previous findings that parks are highly valued public goods, with the creation of new parks in the city of Norwich having the potential to generate substantial value to residents. The low protest bid rate in the sample suggests that not only do residents have strong preferences towards the creation of new parks but that, at least in principle, they are willing to pay for increased provisioning through a familiar and realistic payment vehicle. Using an ex ante valuation allowed values and 
preference motives to be compared for two locations revealing significant differences in both mean WTP and its determinants.

Results of a simple choice experiment of which park should be created revealed that $65 \%$ of the sample would prefer a park to be created at the CC location. While participants were more likely to choose the park closest to them variations in levels of participant's environmental concern also had a significant effect on their park choice, asserting the importance of attitudes in preference formation. A preference for the CC location was also evident in WTP bids with significantly higher mean WTP for the CC location than the SB. This overall preference for the CC location may be attributable to the highly accessible nature of the city centre location. While it is also possible that distance is perceived as a sunk cost for the CC park as people visit the city centre for shopping trips regardless.

Examination of the determinants of WTP for each park reveal consistent differences in the effects of distance. Both the concave quadratic specification of the Tobit and smoothed distance curve of the GAM model indicate that participants prefer to live close to this park but not too close. In contrast WTP for the SB park decreases steadily to a distance of approximately $4000 \mathrm{~m}$ at which point a slight upturn in values occurs. These differences in both the shape and magnitude of distance decay can only be attributed to differences in participant's perceptions of the two locations. The presence of non-monotonic distance decay in WTP values for public parks has implications for the inclusion of distance coefficients in value transfer functions. If disamenities are present but ignored then such functions risk overestimating aggregate values. Furthermore, using the presence of monotonic distance decay as a validation of the theoretical validity of both primary and derived WTP values 
(Bateman et al., 2010) should be avoided unless the possibility of local disamenities is ruled out.

While the authors speculate that fear of crime and anti-social behaviour drive the observed disamenity we offer no empirical test of what it is about the CC parks location that causes this difference in distance decay. This study has also observed varying effects of attitudes on WTP values with increased levels of environmental concern causing a greater increase in WTP for the city centre park location. This supports previous empirical findings that noneconomic motives can be relevant to individuals WTP for goods with non-use value components (Ojea and Loureiro 2007; Cooper, et al. 2004).

In conclusion this study has highlighted the importance of a priori assumptions regarding the functional form of distance decay functions. While Tobit models failed to establish distance as a significant influence on WTP for the CC park the use of smoothing functions in the semi-parametric GAM models reveals clear differences in distance decay between the two parks. Despite the potential presence of local disamenities at the CC park it is still seen to generate higher mean and aggregate values over the study area. 


\section{References}

Anderson S T, West S E, 2006, "Open space, residential property values, and spatial context" Regional Science and Urban Economics 36(6) 773-789

Arrow K, Solow R, Portney P R, Leamer E E, Radner R, Schuman H, 1993, "Report of the NOAA Panel on Contingent Valuation" Federal Register 58(10) 4601-4614

Bateman I J, Brouwer R, Cranford M, Hime S, Ozdemiroglu E, Phang Z, Provins A, 2010,. "Valuing environmental impacts: practical guidelines for the use of value transfer in policy and project appraisal, main report to the department for environment, food and rural Affairs. Economics for the Environment Consultancy(eftec)" London, Published at http://www. defra. gov. uk/environment/policy/natural-environ/documents/guidelines. pdf Bateman I J, Burgess D, Hutchinson W G, Matthews D I, 2008, "Learning design contingent valuation (LDCV): NOAA guidelines, preference learning and coherent arbitrariness" Journal of environmental economics and management 55(2) 127-141

Bateman I J, Day B H, Georgiou S, Lake I, 2006, "The aggregation of environmental benefit values: welfare measures, distance decay and total WTP" Ecological Economics 60(2) 450460

Bateman I J, Langford I H, 1997, "Non-users' willingness to pay for a National Park: an application and critique of the contingent valuation method" Regional studies 31(6) 571-582

Bateman I J, Abson D, Beaumont N, Darnell A, Fezzi C, Hanley N, Kontoleon A, Maddison D, Morling P, Morris J, Mourato S, Pascual U, Perino G, Sen A, Tinch D, Turner K, Valatin G, Andrews B, Asara V, Askew T, Aslam U, Atkinson G, Beharry-Borg N, Bolt K, Cole M, Collins M, Comerford E, Coombes E, Crowe A, Dugdale S, Dunn H, Foden J, Gibbons S, Haines-Young 
R, Hattam C, Hulme M, Ishwaran M, Lovett A A, Luisetti T, MacKerron G, Mangi S, Moran D, Munday P, Paterson J, Resende G, Siriwardena G, Skea J, van Soest D, Termansen M, 2011, "Economic values from ecosystems" in The UK National Ecosystem Assessment, (corp. ed.) Uk National Ecosystem Assessment: Understanding Nature's Value to Society: Technical Report (UNEP-WCMC, Cambridge) pp 1067-1150

Bateman I J, Carson R T, Day B, Hanemann M, Hanley N, Hett T, Jones-Lee M, Loomes G, Mourato S, Özdemiroğlu E, Pearce D W, Sugden R, Swanson J, 2002, Economic valuation with stated preference techniques: a manual (Edward Elgar, Cheltenham UK)

Bateman I J, Brouwer R, Ferrini S, Schaafsma M, Barton D N, Dubgaard A, Hasler B, Hime S, Liekens I, Navrud S, De Nocker L, Sceponaviciute R, Semeniene D, 2011, “Making benefit transfers work: Deriving and testing principles for value transfers for similar and dissimilar sites using a case study of the non-market benefits of water quality improvements across Europe" Environmental and Resource Economics 50(3), 365-387

Boyle K J, Bergstrom J C, 1999, “Doubt, doubts, and doubters: the genesis of a new research agenda?" in Valuing Environmental Preferences: Theory and Practice of the Contingent Valuation Method in the US, EU and Developing Countries Ed. I J Bateman, K G Willis, (New York: Oxford University Press)

CABE, 2006, "Paying for parks: eight models for funding urban green spaces", Commission for Architecture and the Built Environment, London

CABE, 2005, "Does money grow on trees?", Commission for Architecture and the Built Environment, London 
Cooper P, Poe G L, Bateman I J, 2004, "The structure of motivation for contingent values: a case study of lake water quality improvement" Ecological Economics 50(1) 69-82

Davies L M, Batty H, Beck H, Brett K J, Gaston J A, Harris L, Kwiatkowski J, Sadler L, Scholes W R, Sheate R, Wade P, Burgess N, Cooper H I, McKay R, Metcalfe J W, 2011, “Urban Broad Habitat" in The UK National Ecosystem Assessment, (corp. ed.) Uk National Ecosystem Assessment: Understanding Nature's Value to Society: Technical Report (UNEP-WCMC, Cambridge) pp 361-410

Day B, Bateman I J, Lake I, 2007, "Beyond implicit prices: recovering theoretically consistent and transferable values for noise avoidance from a hedonic property price model" Environmental and Resource Economics 37(1) 211-232

Dehring C, Dunse N, 2006, "Housing density and the effect of proximity to public open space in Aberdeen, Scotland" Real Estate Economics 34(4) 553-566

DCLG, 2013, “Council tax levels set by local authorities in England: 2013 to 2014 (revised), Table 1" Department for Communities and Local Government, (The Stationary office, London)

Dijkstra J, van Leeuwen J, Timmermans H, 2003, "Evaluating design alternatives using conjoint experiments in virtual reality" Environment and Planning B: Planning and Design, $30357-367$

Dunse N, White M, Dehring C, 2007, “Urban parks, open space and residential property values" RICS Research paper series 7(8) 0-40 
Espey M, Owusu-Edusei K, 2001, “Neighbourhood parks and residential property values in Greenville, South Carolina" Journal of Agricultural and Applied Economics 33(3) 487-492

Ferrini S, Fezzi C, 2012, “Generalized Additive Models for Nonmarket Valuation via Revealed or Stated Preference Methods" Land Economics 88(4) 782-802

Fujiwara D, Lawton R, Mourato S, 2015, "The health and wellbeing benefits of public libraries" Arts Council England

Garcia X, 2014, "The value of rehabilitating urban rivers: the Yarqon River (Israel)" Journal of Environmental Economics and Policy 3(3) 323-339

Halvorsen B, 1996, "Ordering effects in contingent valuation surveys. Environmental and Resource Economics" 8(4) 485-499

Hanley N, Knight J, 1992, "Valuing the environment: recent UK experience and an application to Green Belt Land" Journal of Environmental Planning and Management 35(2) $145-160$

Hanley N, Schläpfer F, Spurgeon J, 2003, “Aggregating the benefits of environmental improvements: distance-decay functions for use and non-use values" Journal of Environmental Management 68(3) 297-304

Johnston, R.J., Rolfe, J., Rosenberger, R.S. and Brouwer, R. (2015) Introduction to Benefit Transfer Methods, pp19-59 in Johnston, R.J., Rolfe, J., Rosenberger, R.S. and Brouwer, R. (eds.) Benefit Transfer of Environmental and Resource Values, The Economics of Non-Market Goods and Resources 14, Springer Science+Business Media Dordrecht, DOI 10.1007/978-94017-9930-0_2 
Karp D G, 1996, "Values and their effect on pro-environmental behaviour" Environment and Behaviour 28(1) 111-133

Kotchen M J, Reiling S D, 2000, “Environmental attitudes, motivations, and contingent valuation of nonuse values: a case study involving endangered species" Ecological Economics 32(1) 93-107

Laing R, Davies A-M, Miller D, Conniff A, Scott S, Morrice J, 2008, "The application of visual environmental economics in the study of public preference and urban greenspace" Environment and Planning B: Planning and Design 36 355-375

Loomis, J.B. (2012) Comparing households' total economic values and recreation value of instream flow in an urban river, Journal of Environmental Economics and Policy, 1(1):5-17, http://dx.doi.org/10.1080/21606544.2011.640855

Mahieu, P-A., Riera, P., Kriström, B., Brännlund, R., and Giergiczny, M. (2014) Exploring the determinants of uncertainty in contingent valuation surveys, Journal of Environmental Economics and Policy, 3(2): 186-200, http://dx.doi.org/10.1080/21606544.2013.876941 Meyerhoff J, Liebe U, 2006, “Protest beliefs in contingent valuation: explaining their motivation" Ecological Economics 57(4) 583-594

Mitchell R C, Carson R T, 1989, Using surveys to value public goods: the contingent valuation method (Resources for the Future Press)

Natural England, 2010, 'Nature Nearby' Accessible Natural Green space Guidance NE265 (Natural England, London) 
Nordlund A M, Garvill J, 2002, "Value structures behind pro-environmental behaviour" Environment and behaviour 34(6) 740-756

NRC, 2004, Valuing ecosystem services: toward better environmental decision-making, National Research Council (The National Academies Press, Washington, DC)

Ojea E, Loureiro M L, 2007, “Altruistic, egoistic and biospheric values in willingness to pay (WTP) for wildlife" Ecological Economics, 63(4), 807-814.

Pate J, Loomis J, 1997, "The effect of distance on willingness to pay values: a case study of wetlands and salmon in California" Ecological Economics 20(3) 199-207

Rosenberger R S, Loomis J B, 2001, Benefit transfer of outdoor recreation use values: a technical document supporting the Forest Service Strategic Plan (2000 revision), Gen Tech Rep RMRS-GTR-72, CO US Department of Agriculture, Forest Service: Fort Collins

Ryan A, Spash C L, 2008, "Measuring" awareness of Environmental Consequences": Two Scales and Two Interpretations" CSIRO Sustainable Ecosystems Socio-Economics and the Environment in Discussion (SEED) Working Paper Series 2008-101-34.

Salazar D S, Menéndez L G, 2007, "Estimating the non-market benefits of an urban park: Does proximity matter?" Land Use Policy 24(1) 296-305

Schwartz S H, 1992, "Universals in the content and structure of values: Theoretical advances and empirical tests in 20 countries" Advances in experimental social psychology, 25(1), 1-65.

Simpson, R.D. (2016) The simple but not-too-simple valuation of ecosystem services: basic principles and an illustrative example, Journal of Environmental Economics and Policy, 1-11; http://dx.doi.org/10.1080/21606544.2016.1184594 
Slovic P, Lichtenstein S, 1983, „Preference reversals: A broader perspective” The American Economic Review 73(4) 596-605

Stern P C, Dietz T, 1994, "The value basis of environmental concern" Journal of social issues 50(3) 65-84

Stern P C, Dietz T, Black J S, 1985, „Support for environmental protection: The role of moral norms" Population \& Environment 8(3) 204-222

Stern P C, Dietz T, Guagnano G A, 1995, "The new ecological paradigm in socialpsychological context" Environment and behaviour 27(6) 723-743

Stern P C, Dietz T, Kalof L, 1993, "Value orientations, gender, and environmental concern" Environment and behaviour 25(5) 322-348

Stern P C, Kalof L, Dietz T, Guagnano G A, 1995, "Values, Beliefs, and Proenvironmental Action: Attitude Formation Toward Emergent Attitude Objects" Journal of Applied Social Psychology 25(18) 1611-1636

Strazzera E, Genius M, Scarpa R, Hutchinson G, 2003, "The effect of protest votes on the estimates of WTP for use values of recreational sites" Environmental and Resource Economics 25(4) 461-476

Vondolia G K, Eggert H, Navrud S, Stage J, 2014, "What do respondents bring to contingent valuation? A comparison of monetary and labour payment vehicles" Journal of Environmental Economics and Policy 3(3) 253-267 
Whitford V, Ennos A R, Handley J F, 2001, "City form and natural process-indicators for the ecological performance of urban areas and their application to Merseyside, UK" Landscape and Urban Planning 57(2) 91-103

Willis K, Crabtree B, Osman L M, Cathrine K, 2016, “Green space and health benefits: a QALY and CEA of a mental health programme" Journal of Environmental Economics and Policy 5(2) $163-180$

URL: http://mc.manuscriptcentral.com/teep 


\section{Appendixes:}

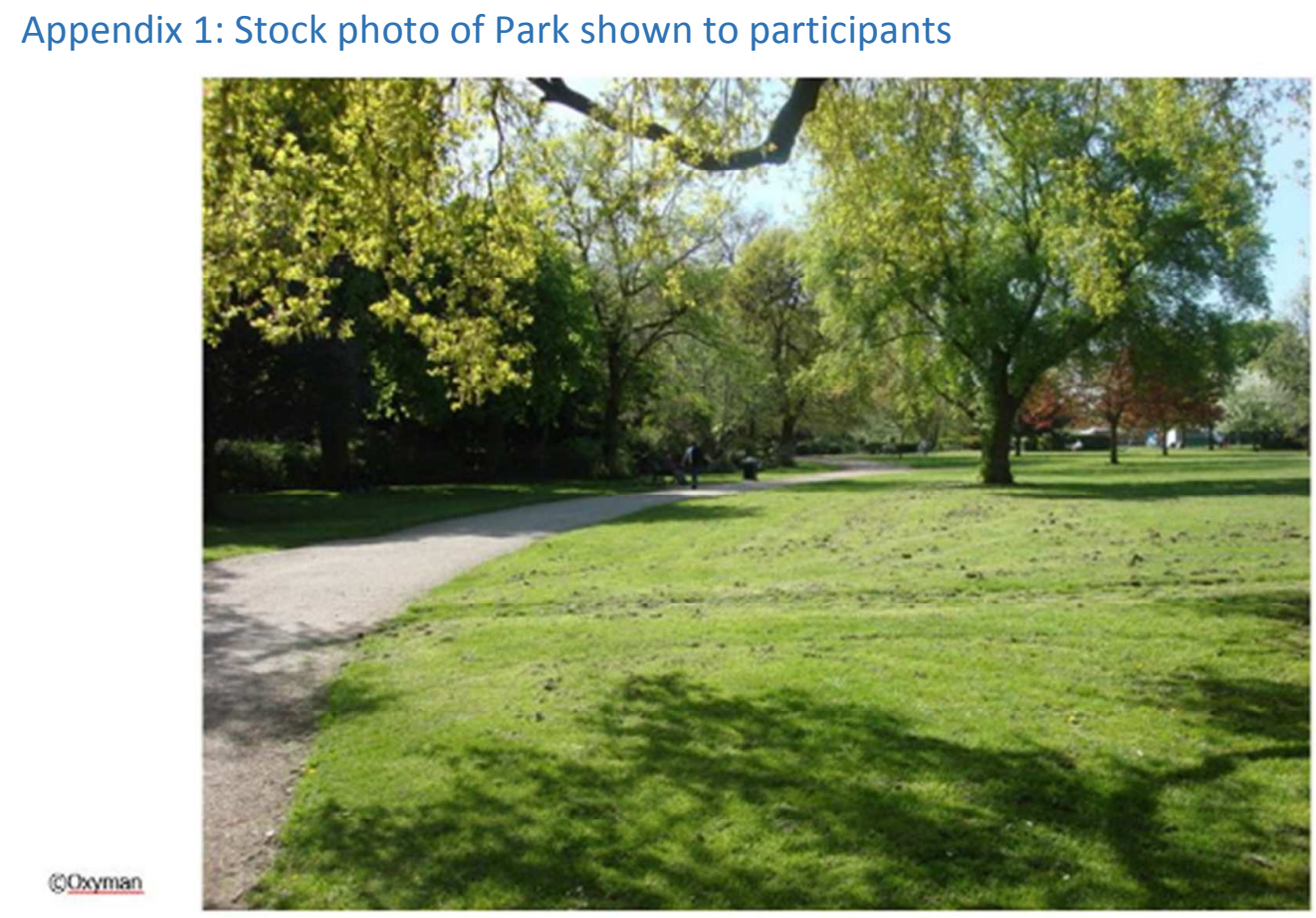




\section{Appendix 2: Payment Ladder Flashcard.}

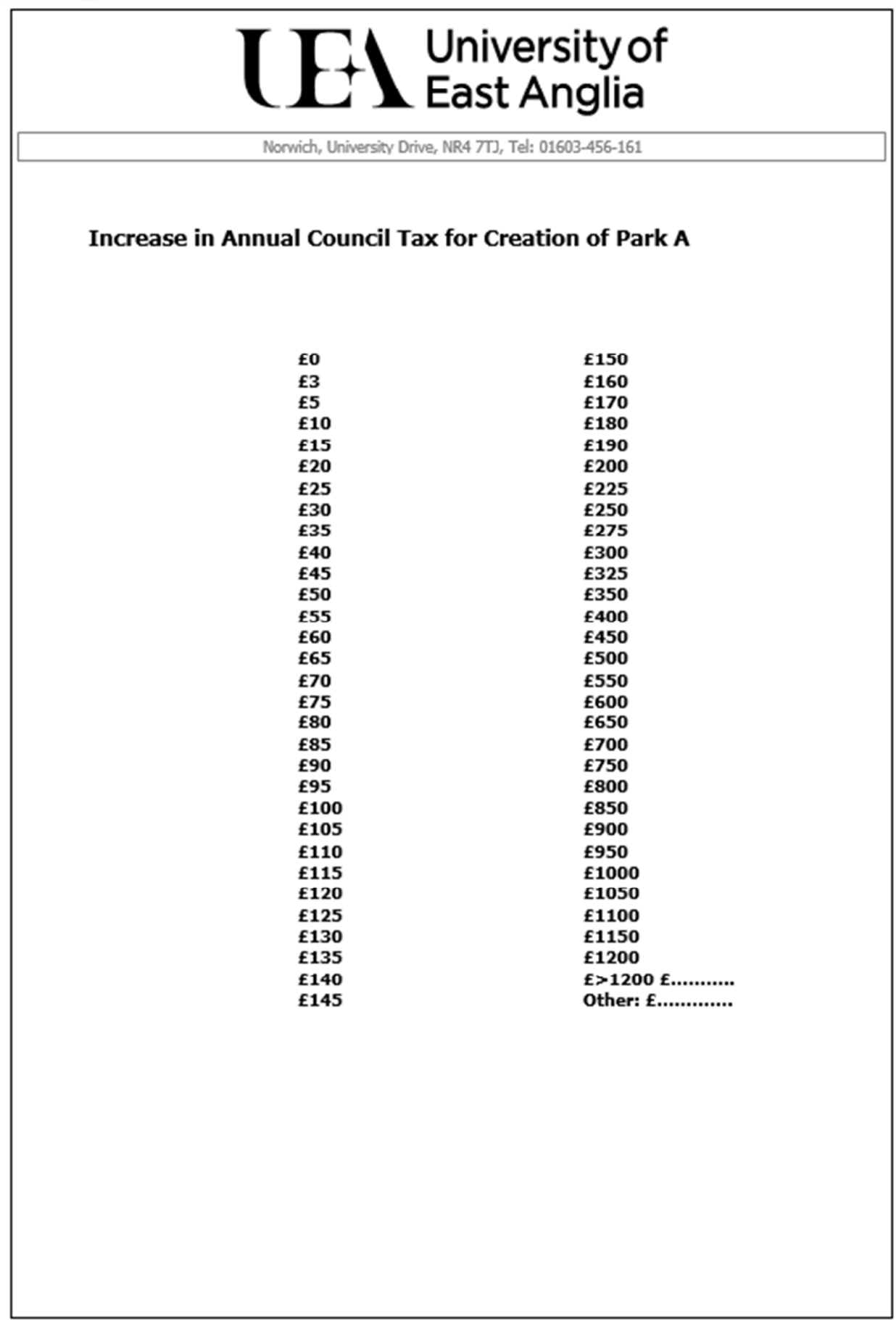

URL: http://mc.manuscriptcentral.com/teep 
Appendix 3: Sample Descriptives

\begin{tabular}{|c|c|c|c|c|c|c|c|c|}
\hline Variable Name & $\mathrm{N}$ & Min & Q1 & Median & Q3 & Max & $\begin{array}{l}\text { Sample Mean } \\
\text { (SD) }\end{array}$ & $\begin{array}{l}\text { Study Area } \\
\text { Mean (SD) }\end{array}$ \\
\hline Gender ( 1 = female) & 270 & 0 & N/A & 1 & N/A & 1 & $\begin{array}{l}.54(\mathrm{Cl} 95 \%= \\
48 \%-60 \%)\end{array}$ & $\begin{array}{l}.50(\mathrm{Cl} 95 \%= \\
50.3-50.7)\end{array}$ \\
\hline $\begin{array}{l}\text { Income (Mid-point } \\
\text { of household income } \\
\text { category) }\end{array}$ & 270 & $£ 3,000$ & $£ 15,000$ & $£ 27,000$ & 45,000 & $£ 75,000$ & $\begin{array}{c}£ 28,867 \\
(£ 19,997) \mathrm{Cl}= \\
£ 26,471- \\
£ 31,263\end{array}$ & $£ 27,251(£ 4918)$ \\
\hline Age & 270 & 16 & 29 & 44 & 59 & 93 & $\begin{array}{c}45 \text { (17.5) years } \mathrm{Cl} \\
=43-48\end{array}$ & $\begin{array}{c}44.9(\mathrm{Cl}=45.8- \\
49.4)\end{array}$ \\
\hline $\begin{array}{l}\text { No. of Dependents } \\
\text { (under 18s) }\end{array}$ & 270 & 0 & 0 & 0 & 1 & 5 & $\begin{array}{c}.69(1.1) \mathrm{Cl}=.55 \\
-.82\end{array}$ & $\begin{array}{c}0.2(\mathrm{Cl}=0.5- \\
0.7)\end{array}$ \\
\hline $\begin{array}{l}\text { GAC total (Mean of } \\
\text { all } 9 \text { GAC scale } \\
\text { items) }\end{array}$ & 270 & 2.4 & 3.6 & 4 & 4.3 & 5 & $\begin{array}{c}3.97(.56) \mathrm{Cl}=3.9 \\
-4.04\end{array}$ & $\mathrm{~N} / \mathrm{A}$ \\
\hline $\begin{array}{l}\text { GAC Altruistic (Mean } \\
\text { of } 3 \text { Altruistic items) }\end{array}$ & 270 & 1.7 & 3.7 & 4 & 4.3 & 5 & $\begin{array}{c}3.95(.65) \mathrm{Cl}= \\
3.88-4.03\end{array}$ & $\mathrm{~N} / \mathrm{A}$ \\
\hline $\begin{array}{l}\text { GAC Biospheric } \\
\text { (Mean of } 3 \\
\text { Biospheric items) }\end{array}$ & 270 & 1.7 & 3 & 3.67 & 4.3 & 5 & $\begin{array}{c}3.70(.80) \mathrm{Cl}= \\
3.60-3.79\end{array}$ & $\mathrm{~N} / \mathrm{A}$ \\
\hline $\begin{array}{l}\text { GAC Egoistic (Mean } \\
\text { of } 3 \text { Egoistic items) }\end{array}$ & 270 & 2 & 4 & 4 & 5 & 5 & $\begin{array}{c}4.25(.61) \mathrm{Cl}= \\
4.18-4.33\end{array}$ & NA \\
\hline $\begin{array}{l}\text { Distance to nearest } \\
\text { park (meters) }\end{array}$ & 270 & 62 & 662 & 1025 & 1191 & 2443 & $\begin{array}{c}981(514) \mathrm{Cl}= \\
920-1043\end{array}$ & $\mathrm{~N} / \mathrm{A}$ \\
\hline Distance to Park A & 270 & 1035 & 2109 & 2699 & 3247 & 5120 & $2792(1038) \mathrm{Cl}=$ & $2273(1108)$ \\
\hline
\end{tabular}




\begin{tabular}{|l|c|c|c|c|c|c|c|c|}
\hline (meters) & & & & & & & $2668-2917$ & \\
\hline $\begin{array}{l}\text { Distance to Park B } \\
\text { (meters) }\end{array}$ & 270 & 388 & 1866 & 3014 & 4390 & 5743 & $\begin{array}{c}3068(1438) \mathrm{Cl}= \\
2896-3240\end{array}$ & 3181 (1299) \\
\hline Use Park A9 & 269 & 1 & 2 & 3 & 3 & 4 & $\begin{array}{c}2.68(.92) \mathrm{Cl}= \\
2.57-2.79\end{array}$ & $\mathrm{~N} / \mathrm{A}$ \\
\hline Use Park B3 & 267 & 1 & 2 & 2 & 3 & 4 & $\begin{array}{c}2.37(.91) \mathrm{Cl}= \\
2.26-2.48\end{array}$ & $\mathrm{~N} / \mathrm{A}$ \\
\hline
\end{tabular}

Comparison of our sample with the study area revealed no significant differences between the underlying distributions age in our sample and those calculated from the 2001 census $^{10}$ for every postcode in the study area $(z=-0.399, p=0.69)$. Income values for the study area postcodes were extracted from the Experian mosaic data set. Comparing these with those of our sample with a two sample Wilcoxon rank sum (Mann-Whitney) test shows that the distribution of incomes is different ( $p 0.0005)$ having a higher rank in the study area.

The spatial representativeness of our sample relative to the two park locations can be seen by comparing the average distance of all postcodes in the study area to that of our sample. While distance to the SB park has a similar average value for all postcodes in the study area, for our sample distance to the CC park is significantly higher for the sample compared to the study area. An independent sample t-test on the distance to park A shows a significant difference between distance to $A$ of our participants and distance to $A$ in the study area $(p=$ 0.0000).

\footnotetext{
${ }^{9}$ Categorical variable representing participants expected usage of the proposed park: $1=$ Definitely use $2=$ Probably use $3=$ Probably not use $4=$ Definitely not use

${ }^{10}$ Mean ages were calculated from mid points of census frequency data for all over $18 \mathrm{~s}$.
} 
Good Parks - Bad Parks: The Infl. of Loc. and Pref. Motives on WTP.

\section{Appendix 4: Tobit Models of WTP}

\begin{tabular}{|c|c|c|c|c|c|c|}
\hline & \multicolumn{3}{|c|}{ WTP CC Park * N = 270 (79 left censored) } & \multicolumn{3}{|c|}{ WTP SB Park + N = 268 (88 left censored) } \\
\hline & Linear & Log & Quadratic $^{11}$ & Linear & Log & Quadratic \\
\hline $\begin{array}{l}\text { Distance } \\
\text { (Linear) }\end{array}$ & $\begin{array}{l}-.0039749 \\
(.0026743)\end{array}$ & & $\begin{array}{l}-.0009867 \\
(.0028632)\end{array}$ & $\begin{array}{c}. \\
.0051329 * * * \\
(.0018093)\end{array}$ & & $\begin{array}{c}- \\
.0051366^{* * *} \\
(.0017812)\end{array}$ \\
\hline Ln Distance & & $\begin{array}{l}-6.810845 \\
(7.16576)\end{array}$ & & & $\begin{array}{c}-14.51143 \\
(4.419909)^{* * *}\end{array}$ & \\
\hline Distance $^{2}$ & & & $\begin{array}{l}(2.30 \mathrm{e}- \\
06)^{* * *}\end{array}$ & & & $\begin{array}{l}2.96 \mathrm{e}-06^{* *} \\
(1.39 \mathrm{e}-06)\end{array}$ \\
\hline GAC & $\begin{array}{l}13.02284^{* * *} \\
(4.875385)\end{array}$ & $\begin{array}{c}13.60391 * * * \\
(4.859375)\end{array}$ & $\begin{array}{c}11.42336 \\
(4.82753)^{* *}\end{array}$ & $\begin{array}{c}3.22158 \\
(4.495875)\end{array}$ & $\begin{array}{c}3.1583 \\
(4.456687)\end{array}$ & $\begin{array}{l}2.706739 \\
(4.45137)\end{array}$ \\
\hline Income & $\begin{array}{l}.0002567^{*} \\
(.000132)\end{array}$ & $\begin{array}{l}.0002533^{*} \\
(.0001324)\end{array}$ & $\begin{array}{l}.0002114 \\
(.000131)\end{array}$ & $\begin{array}{l}.0003131^{* *} \\
(.000128)\end{array}$ & $\begin{array}{c}.0003114 \\
(.0001261)^{* *}\end{array}$ & $\begin{array}{l}.0002986^{* *} \\
(.0001267)\end{array}$ \\
\hline $\begin{array}{l}\text { No. of } \\
\text { Dependents in } \\
\text { Household }\end{array}$ & $\begin{array}{c}-5.497549 * * \\
(2.46747)\end{array}$ & $\begin{array}{l}-5.554504^{* *} \\
(2.470393)\end{array}$ & $\begin{array}{l}-5.66972 * * \\
(2.429829)\end{array}$ & $\begin{array}{l}-4.510092 * \\
(2.311832)\end{array}$ & $\begin{array}{c}-4.591721 \\
(2.289304)^{* *}\end{array}$ & $\begin{array}{l}-4.533405^{*} \\
(2.284023)\end{array}$ \\
\hline Constant & $\begin{array}{l}-29.97609 \\
(22.0898)\end{array}$ & $\begin{array}{c}10.35501 \\
(61.54)\end{array}$ & $\begin{array}{l}-26.68489 \\
(20.15296)\end{array}$ & $\begin{array}{c}7.106661 \\
(18.26694)\end{array}$ & $\begin{array}{c}106.2465 \\
(36.94295)^{* * *}\end{array}$ & $\begin{array}{l}-12.12288 \\
(18.24875)\end{array}$ \\
\hline $\mathrm{R}^{2}$ & 0.0084 & 0.0078 & 0.0119 & 0.0064 & 0.0077 & 0.0087 \\
\hline
\end{tabular}

Significance Levels: $*=\mathrm{p}<0.1, * *=\mathrm{p}<0.05, * * *=\mathrm{p}<0.01$

\section{Appendix 5: Spatial Data Used for Aggregation}

Spatially referenced out of sample data for the variables used in the Tobit and GAM models above were collated from a range of sources. While it was possible to calculate distance to

\footnotetext{
${ }^{11}$ Without mean centering the park A linear distance coefficient $=0.339 * *$ and the squared coefficient $=$ $0.000006^{* * *}$ for park B the linear distance coefficient $=-0.232^{* * *}$ and the squared coefficient $=0.000002^{* *}$.
} 
Good Parks - Bad Parks: The Infl. of Loc. and Pref. Motives on WTP.

each of the parks using postcode centroids and the OS ITN, Median household incomes had to be obtained from the Experian Mosaic data sets at the much larger LSOA level. To parameterise the number of dependents in the household for out of sample households, population data from the 2001 census was used to calculate the average number of dependents per household at the census output area scale. Thus, there is significantly less spatial variation in these two measures than in the distance measures. Finally, as no GAC score data was available for out of sample households the mean GAC score was used. These variables were collected for all the postcodes in both the study area $(2,743$ postcodes $)$ and a 5000 metre road based service area of each respective park centroid $(4,192$ postcodes for park $A$ and 3,354 postcodes for park SB). 
Good Parks - Bad Parks: The Infl. of Loc. and Pref. Motives on WTP.

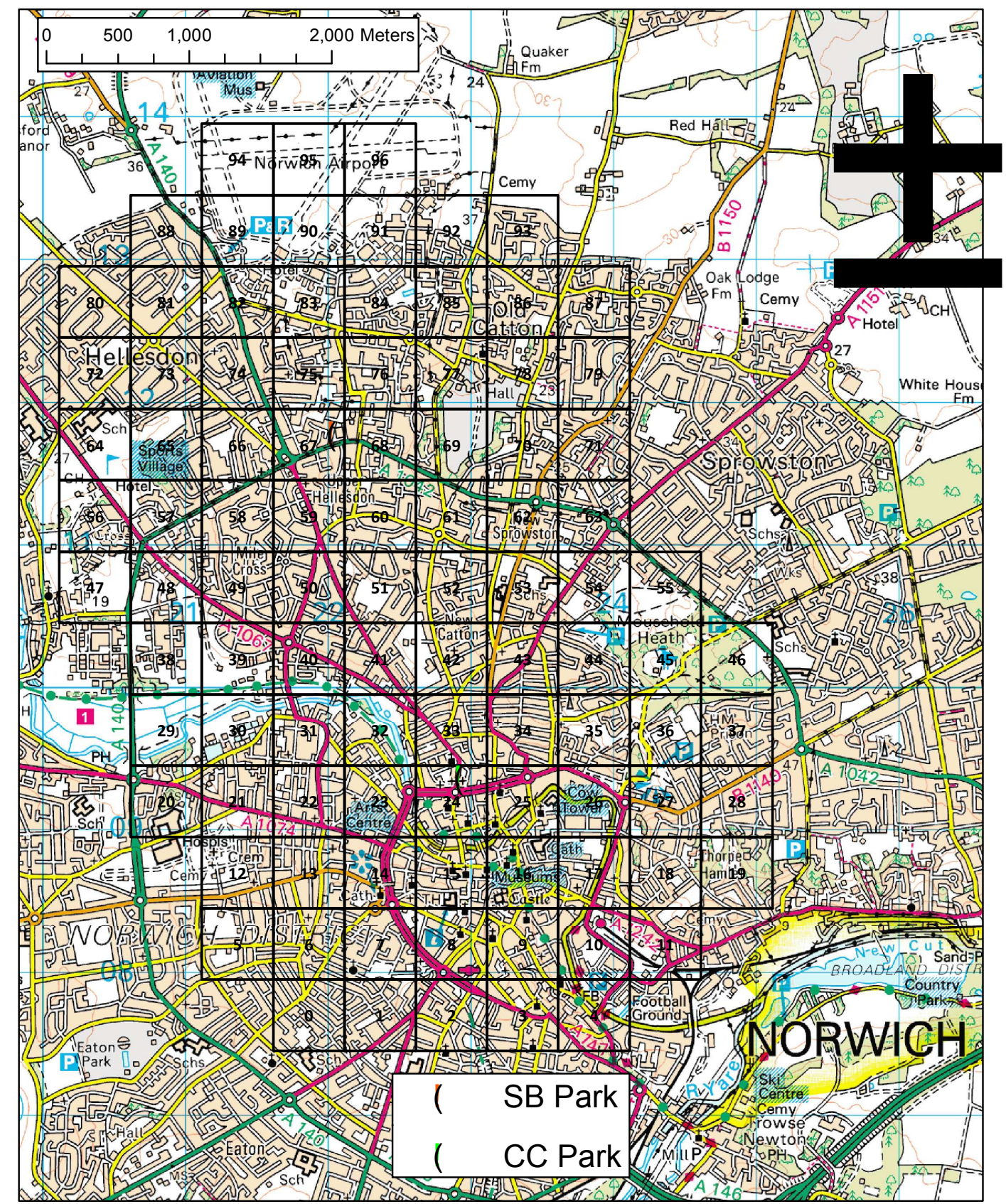

Figure 1: Study area showing 96 sampling squares and sites of proposed Parks.

(Crown Copyright, Ordnance Survey Ltd.) 
Good Parks - Bad Parks: The Infl. of Loc. and Pref. Motives on WTP.

Table 1: Cross-tabulation of park choice preferences.

\begin{tabular}{|c|c|c|c|c|}
\hline & \multirow{3}{*}{$\begin{array}{c}\text { Choose CC Park } \\
165\end{array}$} & \multirow{3}{*}{$\begin{array}{c}\text { Choose SB Park } \\
37\end{array}$} & \multirow{3}{*}{\begin{tabular}{|l|} 
Total \\
202
\end{tabular}} \\
\hline & & & & \\
\hline Closer & Count & & & \\
\hline to $\mathrm{CC}$ & $\%$ of total sample & 45 & 10 & 53 \\
\hline \multirow{2}{*}{$\begin{array}{l}\text { Closer } \\
\text { to SB }\end{array}$} & Count & 81 & 96 & 177 \\
\hline & $\%$ of total sample & 21 & 25 & 47 \\
\hline \multirow{2}{*}{ Total } & Count & 246 & 133 & 379 \\
\hline & $\%$ of total sample & 65 & 35 & 100 \\
\hline
\end{tabular}


Good Parks - Bad Parks: The Infl. of Loc. and Pref. Motives on WTP.

Table 2: Probit park choice model, (1=choose park SB), N=374.

\begin{tabular}{|c|c|c|c|}
\hline Variable & $\begin{array}{c}\text { Coefficient } \\
\text { (s.e.) }\end{array}$ & Z & $P>Z$ \\
\hline Log Distance to CC Park & $\begin{array}{c}0.95 \\
(0.22)\end{array}$ & 4.42 & $0.000 * * *$ \\
\hline Log Distance to SB Park & $\begin{array}{l}-0.41 \\
(0.13)\end{array}$ & -3.10 & $0.000 * * *$ \\
\hline Use SB Park & $\begin{array}{l}0.89 \\
(0.16)\end{array}$ & 5.62 & $0.000 * * *$ \\
\hline Mean of all GAC items & $\begin{array}{l}-0.31 \\
(0.13)\end{array}$ & -2.35 & $0.019 * *$ \\
\hline Intercept & $\begin{array}{l}-4.04 \\
(2.22)\end{array}$ & -1.82 & $0.069 *$ \\
\hline Pseudo $\mathrm{R}^{2}$ & 0.24 & \multirow{2}{*}{\multicolumn{2}{|c|}{ ()) }} \\
\hline$P$ & $0.000 * * *$ & & \\
\hline
\end{tabular}

Significance levels: ${ }^{* * *}=0.01 ; * *=0.05 ; * 0.10$

41

URL: http://mc.manuscriptcentral.com/teep 
Good Parks - Bad Parks: The Infl. of Loc. and Pref. Motives on WTP.

Table 3: Mean WTP ( $€$ ) Missing income, protest and bids $>£ 150$ removed and Breakdown of bids (N's in parenthesis). Mean WTP for both parks $=£ 31.71(\mathrm{~N}=270)$.

\begin{tabular}{|c|c|c|c|c|c|c|c|c|}
\hline & $\begin{array}{c}\text { Protest } \\
\text { Zeros }\end{array}$ & $\begin{array}{c}\text { Genuine } \\
\text { Zeros }\end{array}$ & $\begin{array}{l}\text { Mean } \\
\text { WTP }\end{array}$ & & $\mathrm{N}$ & $\begin{array}{c}\text { Mean } \\
\text { Distance }\end{array}$ & $\begin{array}{c}\text { Mean WTP } \\
\text { (f) } \\
\text { (s.d.) }\end{array}$ & $\begin{array}{l}\text { Mean } \\
\text { GAC }\end{array}$ \\
\hline CC & \multirow{2}{*}{64} & \multirow{2}{*}{90} & \multirow{2}{*}{$\begin{array}{r}f 23.14 \\
(270)\end{array}$} & Users & 191 & $\begin{array}{c}2598 \\
(972)^{* *}\end{array}$ & $\begin{array}{l}30.06 \\
(35.18)\end{array}$ & $\begin{array}{l}4.04 \\
(.57)\end{array}$ \\
\hline Park & & & & $\begin{array}{l}\text { Non- } \\
\text { Users }\end{array}$ & 129 & $\begin{array}{c}3195 \\
(1101)^{* *}\end{array}$ & $\begin{array}{c}12.60 \\
(25.02)\end{array}$ & $\begin{array}{l}3.85 \\
(.55)\end{array}$ \\
\hline \multirow{2}{*}{$\begin{array}{l}\text { SB } \\
\text { Park }\end{array}$} & \multirow[t]{2}{*}{61} & \multirow[t]{2}{*}{104} & f19.11 & Users & 141 & $\begin{array}{c}2487 \\
(1316)^{* *}\end{array}$ & $\begin{array}{l}27.10 \\
(35.12)\end{array}$ & $\begin{array}{l}3.88 \\
(.56)\end{array}$ \\
\hline & & & (268) & $\begin{array}{l}\text { Non- } \\
\text { Users }\end{array}$ & 177 & $\begin{array}{c}3524 \\
(1365)^{* *}\end{array}$ & $\begin{array}{c}12.27 \\
(20.26)\end{array}$ & $\begin{array}{l}4.03 \\
(.56)\end{array}$ \\
\hline
\end{tabular}


Good Parks - Bad Parks: The Infl. of Loc. and Pref. Motives on WTP.

Table 4: Frequency of choices to test for reversal of preferences

\begin{tabular}{|l|c|c|}
\cline { 2 - 3 } \multicolumn{1}{c|}{} & Choose CC & Choose SB \\
\hline Frequency of WTP CC > WTP SB & 97 & 4 \\
\hline Frequency of WTP CC < WTP SB & 3 & 42 \\
\hline
\end{tabular}


Good Parks - Bad Parks: The Infl. of Loc. and Pref. Motives on WTP.

Table 5: WTP regression models (standard errors in parenthesis).

\begin{tabular}{|c|c|c|c|c|}
\hline \multirow[t]{2}{*}{ Predictors } & \multicolumn{2}{|c|}{ Tobit } & \multicolumn{2}{|c|}{ GAM } \\
\hline & CC Park & SB Park & CC Park & SB Park \\
\hline Distance & $0.034 * *(0.014)$ & $\begin{array}{c}-0.023 \\
(0.009)^{* * *}\end{array}$ & $\begin{array}{l}\text { Smoothed } \\
\text { Distance: }\end{array}$ & $\begin{array}{l}\text { Smoothed } \\
\text { Distance: }\end{array}$ \\
\hline Distance (sqrd) & $\begin{array}{c}-0.000006^{* * *} \\
(0.000002)\end{array}$ & $\begin{array}{l}0.000003^{* *} \\
(0.000001)\end{array}$ & $\begin{array}{l}\text { Edf }=2.28 \text { Ref.df }= \\
2.849 P=0.047^{* *}\end{array}$ & $\begin{aligned} \text { Edf } & =1.859 \text { Ref.df } \\
& =2.341 \mathrm{P}= \\
& 0.0007^{* * *}\end{aligned}$ \\
\hline GAC & $\begin{array}{c}11.423 * * \\
(4.828)\end{array}$ & $\begin{array}{c}2.707 \\
(4.451)\end{array}$ & $\begin{array}{c}0.29 \\
(0.14)^{* *}\end{array}$ & $\begin{array}{c}0.08 \\
(0.14)^{* *}\end{array}$ \\
\hline Income & $\begin{array}{l}.0002 \\
(.0001)\end{array}$ & $\begin{array}{l}.0003^{* *} \\
(.0001)\end{array}$ & $\begin{array}{l}-0.20 \\
(0.09)^{*}\end{array}$ & $\begin{array}{c}-0.22 \\
(0.08)^{* *}\end{array}$ \\
\hline No. of Dependents & $\begin{array}{c}-5.670 * * \\
(2.430)\end{array}$ & $\begin{array}{c}-4.533^{* *} \\
(2.284)\end{array}$ & $\begin{array}{c}0.000006 \\
(0.000003)^{* *}\end{array}$ & $\begin{array}{c}0.000008 \\
(0.000004)^{* *}\end{array}$ \\
\hline Constant & $\begin{array}{c}-72.913^{* * *} \\
(27.029)\end{array}$ & $\begin{array}{c}31.378 \\
(21.286)\end{array}$ & $\begin{array}{c}1.86 \\
(0.58)^{* * *}\end{array}$ & $\begin{array}{c}2.49 \\
(0.59)^{* * *}\end{array}$ \\
\hline $\mathrm{R}^{2}$ & .060 & 0.066 & $\begin{array}{l}R^{2}=0.05(8.68 \% \\
\text { Var. Explained) }\end{array}$ & $\begin{array}{l}\mathrm{R}^{2}=0.06(7.97 \% \\
\text { Var. Explained) }\end{array}$ \\
\hline $\mathrm{N}$ & $\begin{array}{l}270 \text { (79 left } \\
\text { censored) }\end{array}$ & $\begin{array}{l}268 \text { (88 left } \\
\text { censored) }\end{array}$ & 270 & 268 \\
\hline
\end{tabular}


Good Parks - Bad Parks: The Infl. of Loc. and Pref. Motives on WTP.

1

2

3

4

5

6

7

8

9

10

11

12

13

14

15

16

17

18

19

20

21

22

23

24

25

26

27

28

29

30

31

32

33

34

35

36

37

38

39

40

41

42

43

44

45

46

47

48

49

50

51

52

53

54

55

56

57

58

59

60

Figure 2: Estimated canonical parameters distance decay functions (equal to the linear predictor) for
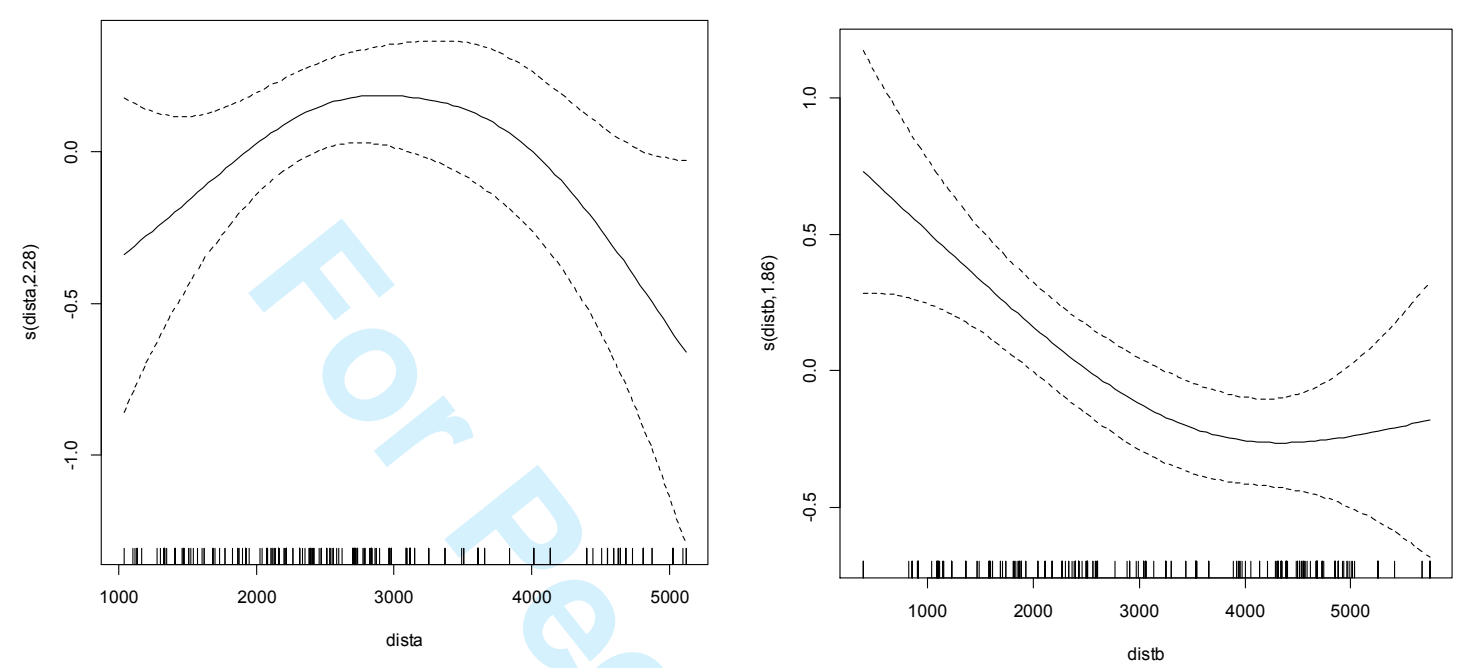

distance to CC park (left) and distance to SB park (right). 
Good Parks - Bad Parks: The Infl. of Loc. and Pref. Motives on WTP.

Figure 3: Predicted WTP values (in sample) distributions for parks A and B (left Tobit model, right GAM).
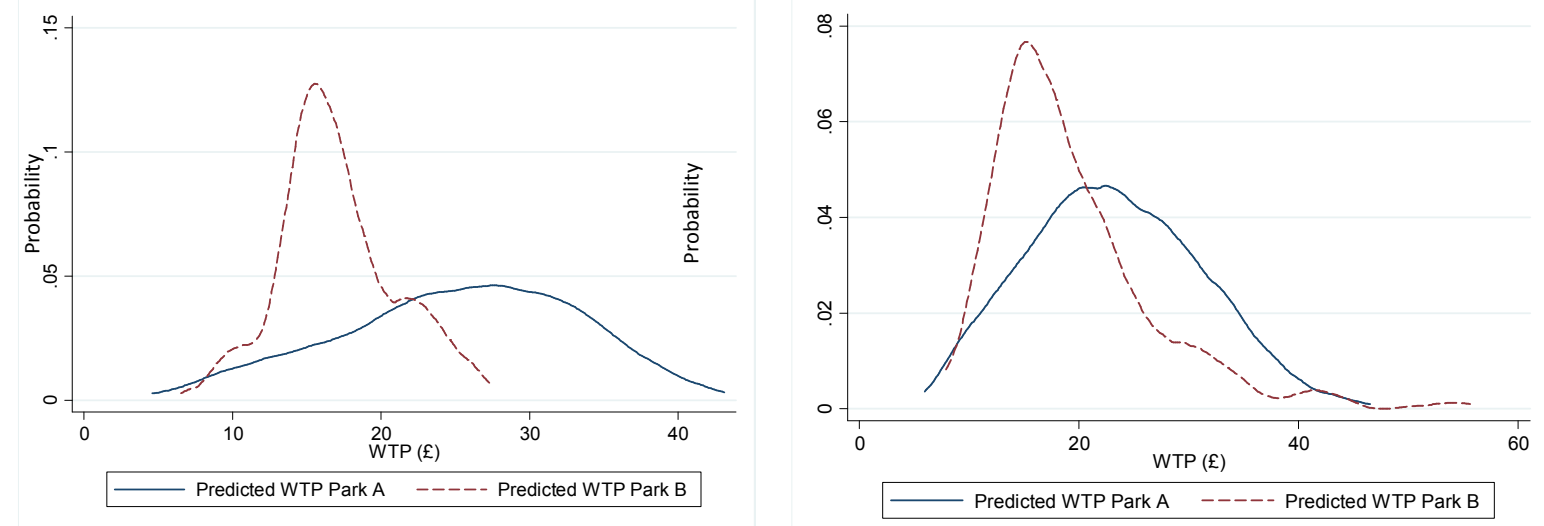

21

22

23

24

25

26

27

28

29

30

31

32

33

34

35

36

37

38

39

40

41

42

43

44

45

46

47

48

49

50

51

52

53

54

55

56

57

58

59

60 
Good Parks - Bad Parks: The Infl. of Loc. and Pref. Motives on WTP.

Figure 4: Predicted WTP by Tobit model (quadratic distance) $f$ per household (no protestors) for the

1

2

3

4

5

6

7

8

9

10

11

12

13

14

15

16

17

18

19

20

21

22

23

24

25

26

27

28

29

30

31

32

33

34

35

36

37

38

39

40

41

42

43

44

45

46

47

48

49

50

51

52

53

54

55

56

57

58

59

60

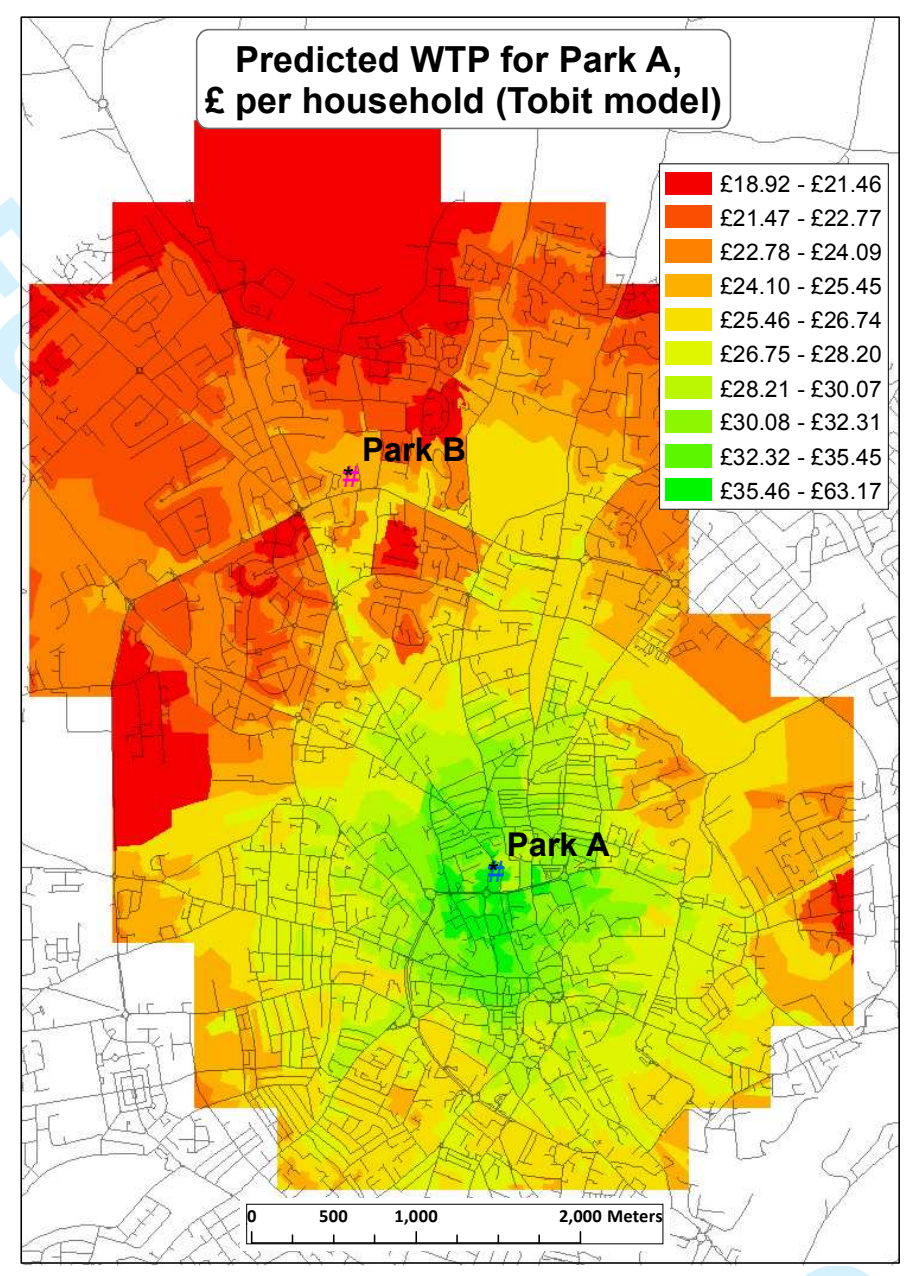

study area (2740 postcodes).

(Crown Copyright, Ordnance Survey Ltd.) 
Good Parks - Bad Parks: The Infl. of Loc. and Pref. Motives on WTP.

Figure 5: Predicted WTP (GAM model) $f$ per household for the study area (2740 postcodes)

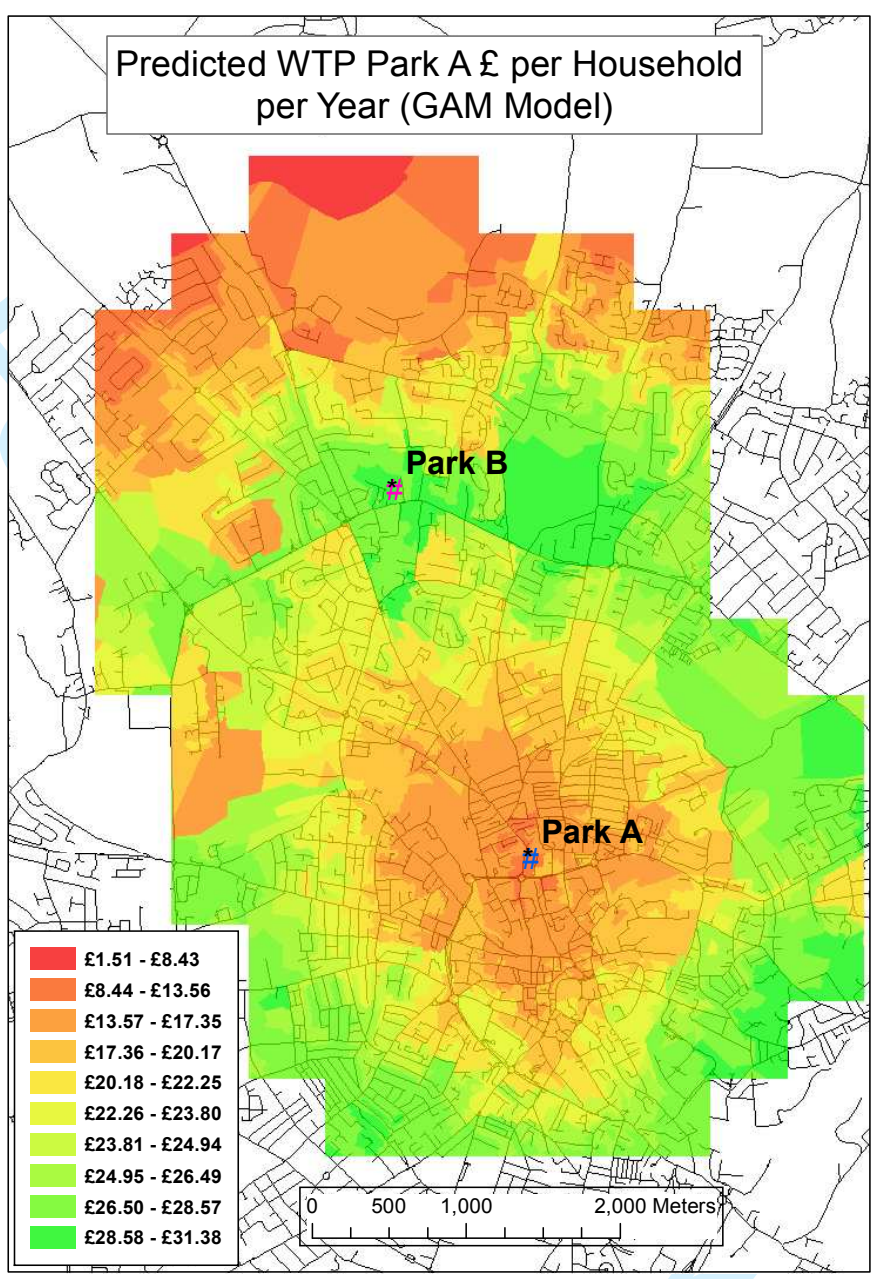

(Crown Copyright, Ordnance Survey Ltd.) 
Good Parks - Bad Parks: The Infl. of Loc. and Pref. Motives on WTP.

Table 6: Tobit and GAM Model based aggregations for the study area and a ten mile buffer of Norwich. Simple aggregations are based on a mean WTP of $£ 23.14$ for the CC park and $£ 19.11$ for the SB.

\begin{tabular}{|c|c|c|c|c|}
\hline & \multicolumn{2}{|c|}{$\begin{array}{c}\text { Study Area }=49,591 \text { households } \\
\text { in } 2,743 \text { postcodes }\end{array}$} & \multicolumn{2}{|c|}{$\begin{array}{l}\text { Ten Mile Aggregation }=106,57 \\
\text { households in } 6,442 \text { postcodes }\end{array}$} \\
\hline & CC Park & SB Park & CC Park & SB Park \\
\hline $\begin{array}{l}\text { Aggregation based on mean } \\
\text { WTP (bids }>150 \text { protest zeros } \\
\text { and missing incomes removed) }\end{array}$ & $£ 1,147,536$ & f947,684 & $£ 2,466,169$ & $£ 2,036,667$ \\
\hline $\begin{array}{l}\text { Tobit aggregation Model } \\
\text { (protests removed) }\end{array}$ & $f 1,297,971$ & $f 1,005,133$ & $f 2,484,897$ & $£ 1,846,733$ \\
\hline $\begin{array}{l}\text { Tobit aggregation Model (6.5\% } \\
\text { of households zero) }\end{array}$ & $f 1,140,256$ & $f 886,763$ & $£ 2,323,379$ & $f 1,726,695$ \\
\hline $\begin{array}{l}\text { Aggregation based on GAM } \\
\text { model with (protests removed) }\end{array}$ & $f 1,114,849$ & $£ 905,259$ & $£ 1,863,520$ & $f 1,909,985$ \\
\hline $\begin{array}{l}\text { Aggregation based on GAM } \\
\text { model ( } 6.5 \% \text { households zero) }\end{array}$ & $f 1,042,384$ & f846,417 & $f 1,742,392$ & $f 1,785,836$ \\
\hline
\end{tabular}

